\title{
How to Use Modern Teaching Methods to Cultivate Students' Autonomous Learning Ability
}

\author{
Weili Su \\ School of Foreign Languages and Culture, Beijing Wuzi University, Beijing, China \\ Email: suweili2007@163.com
}

How to cite this paper: Su, W.L. (2021) How to Use Modern Teaching Methods to Cultivate Students' Autonomous Learning Ability. Open Access Library Journal, 8: e7232.

https://doi.org/10.4236/oalib.1107232

Received: February 8, 2021

Accepted: March 27, 2021

Published: March 30, 2021

Copyright $\odot 2021$ by author(s) and Open Access Library Inc.

This work is licensed under the Creative Commons Attribution International License (CC BY 4.0).

http://creativecommons.org/licenses/by/4.0/ (c) (i) Open Access

\begin{abstract}
Starting with Modern Educational Technology, this paper discusses how to use modern teaching methods to explore new teaching ways and teaching methods to improve students' autonomous learning ability, including updating teaching contents, using network resources to expand students' horizons, enhancing the students' subjectivity, experience and interest in classroom activities and changing the teachers' role orientation.
\end{abstract}

\section{Subject Areas}

Education

\section{Keywords}

Modern Educational Technology, Autonomous Learning, College English Teaching

\section{Introduction}

Modern Educational Technology is a theory and practical technology based on modern educational theory, using modern scientific and technological achievements and systematic science to improve teaching efficiency and optimize the process of education and teaching, it solves the problem of education and teaching by studying the learning process and learning resources. It is necessary for college English teaching and Modern Language teaching theory to cultivate college students' autonomous learning ability, and it is also a strong guarantee for improving English teaching efficiency. In recent years, the rapid development of computer network technology has brought about great progress in educational facilities and methods. At present, colleges and universities are making full use 
of multimedia and network technology and adopting new teaching models to improve the original single teaching model which is mainly taught by teachers. Supported by modern information technology, especially network technology, college English teaching is not limited by time and place, and is developing towards individualized learning and autonomous learning. How to cultivate students' autonomous learning ability by means of modern educational technology is an important task faced by every college English teacher. This paper discusses how to use modern teaching methods to explore new teaching ways and teaching methods to improve students' autonomous learning ability, including updating teaching contents, using network resources to expand students' horizons, enhancing the students' subjectivity, experience and interest in classroom activities and changing the teachers' role orientation.

\section{Making Full Use of Modern Teaching Methods to Change College English Teaching into Autonomous Learning}

Contemporary Language Learning theories emphasize the decisive role of learners in the learning process and learner autonomy. A large number of researches show that the most important factor in language teaching is the learner rather than the teacher, and the teaching should be student-centered, with the student as the main body of teaching [1]. Therefore, English teaching should be a skill-building course to cultivate students' learning ability rather than a knowledge-learning course to instill knowledge into students. Self-regulated learning is a new learning mode, which means that the students under the guidance of teachers should have their own ideas and take the initiative to learn, and the original meaning is that the teachers turn from "talking" to "guiding", and the students turn from other-oriented learning to self-regulated learning. As we advance the liberal education today, we need to establish an important concept: to enable students to fully engage in the teaching process. According to the common theory of learning, students' high-level inquiry is a kind of learning activity. The concept of "autonomous learning" emphasizes students' participation in the teaching and learning process as the main body, and the aim is to change the traditional passive learning, to be proactive, participatory, Project-based learning.

\subsection{Improving Students' Learning Efficiency}

By using modern educational technology and by developing and utilizing English teaching resources, teachers can greatly improve students' learning efficiency.

When conditions permit, teachers should make full use of all kinds of auditory and visual means, such as pictures, audio and video, to enrich the content and form of teaching and to promote students' subjective status in classroom learning. The subject status of students is the prerequisite for teaching to follow the principle of activity. In the activity, the student is the host, the whole activity can 
be participated by the student autonomously. Through self-study, autonomy, self-care, they overcome all kinds of difficulties, and through all kinds of exercise, they become more and more independent, self-consciouse, full of creativity, and all aspects of the ability will be trained and developed. Without students' subjective status, "autonomous learning activities" will no longer exist [2].

\subsection{Promoting Students' Individual Study and Highlight the Experience of Activities}

By using computer and multimedia teaching software, new teaching mode is explored to promote students' individual study and highlight the experience of activities.

Activity-based English teaching which highlights the experience of activities differs from traditional English teaching in that it pays more attention to the teaching process than to the teaching results [3]. What students experience and exercise in the course of teaching is the most important part of autonomous learning. Individual independent learning experience, especially active exploration, discovery behavior, will give students a real psychological feeling, leaving a very deep impression, cannot be forgotten. They can also be used flexibly in new situations and have a good understanding of the essence of what they have learned. Nowadays, it is necessary to emphasize the experience of learning activities when we advocate the exploration of new English teaching methods.

\subsection{Increasing the Interest of English Learning}

By developing and using radio and television, English newspapers and periodicals, libraries, the internet and other resources conditions will be created for students to learn independently, thus the interest of English learning will be increased.

English teaching following the principle of activity should, as far as possible, follow the psychological laws of students, meet their physiological and psychological needs, and arouse their curiosity through interesting activities [4], including the arrangement of various links with interesting characteristics, arouse their interest in learning and attract them to activities. Let students learn while having fun, and learn while doing things, so to consolidate the development of their interests in the continuous activities. This kind of happy English can promote students' autonomy and improve their learning efficiency.

\section{Applying Modern Educational Technology to Change the Role Orientation of English Teachers}

Modern educational technology which is widely used in teaching, undoubtedly brings new vitality and great impact to education, and puts forward higher requirements for teachers. It not only requires teachers to have advanced professional knowledge, rich teaching experience and high teaching level, but also modern educational thoughts and techniques. They must master the computer, 
the multimedia, the network teaching related knowledge and the ability to utilize the modern education methods. The Internet and other network resources enable teachers and students, students and students to exchange information and learn from each other. Students can also use their spare time for individual learning. The English teaching mode under the modern educational technology needs teachers to change from the center of the teaching process to the organizer, the instructor, the helper and the evaluator [5].

As the organizer, teachers must first do well the curriculum design, including the learning objectives of the course, the knowledge points of each chapter, the formulation of learning strategies, the selection of learning media, the content and methods of learning evaluation, the layout of learning process, the determination of learning topics, etc. Secondly, he should grasp the overall learning situation of students, including learning progress, learning effects and so on.

As the guide, teachers should clarify the learning objectives of the course, introduce the learning contents, indicate the learning approaches and guide the learning methods, especially strengthen the guidance of the learning methods under the information technology. In order to carry out this task, teachers are required to provide students with effective learning approaches according to the knowledge distribution, structure and learning methods of college English courses in an information-based learning environment, to understand the new problems in autonomous learning and cooperative learning, and to give correct guidance in time. Teachers are also required to make use of online marking of assignments and online thematic discussion to keep abreast of students' learning and help students in their online help-seeking activities.

\section{Setting up New Teaching Environment and New Talent-Training Model}

To set up a new teaching environment by using modern teaching means, the first step is to design a three-dimensional talent-training model of "cross-discipline and comprehensive knowledge education" [6]. Modern Society is characterized by the infiltration of science and technology and social life, with the more and more comprehensive application of multi-disciplinary and multi-technology, the era of relying on a single one discipline to design and manufacture is gone forever. It is necessary to construct a "three-dimensional training model" with teaching activities, scientific experiments and social practice as its main contents, so that students can learn their professional knowledge well, and at the same time actively participate in scientific research and social practice, so as to cultivate students' active learning, and the spirit of constant pursuit of new knowledge.

The modern theory of talent growth holds that although the innovative activities of the main body of talent should be based on a certain level of intelligence, the intelligence factor is not the fundamental reason for talent development, and the success of talent depends on the formation and development of the main body's innovative personality. Because the innovation process is not only a pure 
intellectual activity process, but also includes many personality psychological character factors, colleges and universities should make full use of modern teaching means to attach importance to the development of personality, cultivating innovative personality, and play their due function and role in training College students ambitious ideals, firm beliefs, rich emotions, strong will, strong interest, continuous self-study ability and other excellent quality.

\section{Conclusion}

The combination of modern information technologies such as multimedia and network technology with the "student-centered and teacher-led" college English teaching model, for students to learn English provides a broad, flexible and creative learning space. In the process of English teaching, teachers should be innovative to learn the latest educational teaching theory, multimedia and network technology, and give full play to the functions of teachers as organizers, coordinators, helpers and guides, explore new teaching methods, constantly update the teaching content, make use of network resources to open up students' vision, and enhance the students' subjectivity, personal experience and interest in classroom activities, to improve students' autonomous learning ability.

\section{Conflicts of Interest}

The author declares no conflicts of interest regarding the publication of this paper.

\section{References}

[1] Gao, P. and Zhang, X.Z. (2005) Cultivation of Learner's Learning Autonomy in College English Classroom. Foreign Language World, No. 1, 33-39.

[2] Holec, H. (1981) Autonomy and Foreign Language Learning. Pergarmon Press, Oxford.

[3] Engestrom, Y. (1987) Learning by Expanding: An Activity-Theoretical Approach to Developmental Research. Orienta-Konsultit, Helsinki, Finland.

[4] Wang, D.Q. (2002) Cultivation of College English Autonomous Learning Ability. Foreign Language World, No. 5, 17-20.

[5] Wu, J. and Wu, Z.J. (2004) Self-Directed Foreign Language Learning in the Computer Network Environment. Journal of Chongqing University, No.10, 119-121.

[6] Wu, J.Z. (2005) The Guide of Constructivism Learning Theory to Cultivating College Students' Self-directed Learning Ability in the New Situation. China Education Guide, No. 6, 98-100. 